Article

\title{
Adaptability of Narrow-Crowned Norway Spruce Ideotype (Picea abies (L.) Karst. pendula Form) in 25 Years Half-Sib Comparative Trials in the Eastern Carpathians
}

\author{
Ecaterina Nicoleta Apostol ${ }^{\mathbf{1}}$ and Marius Budeanu ${ }^{2, *}$ \\ 1 National Institute for Research and Development in Forestry “Marin Drăcea”, Voluntari, \\ 128 Eroilor Boulevard, 077190 Ilfov County, Romania; ecaterina.apostol@icas.ro \\ 2 National Institute for Research and Development in Forestry "Marin Drăcea", Braşov Research Station, \\ 13 Cloşca street, 500040 Braşov, Romania \\ * Correspondence: marius.budeanu@icas.ro; Tel.: +40-726-009-162
}

Received: 12 March 2019; Accepted: 4 May 2019; Published: 6 May 2019

\begin{abstract}
This study analysed the stability of the narrow-crowned Norway spruce (pendula form) compared with the classic form of spruce (pyramidalis form) in two half-sib field trials located in the Romanian Carpathians. From eight natural populations, representative of three of the four large spruce spread areas in Romania, open-pollinated seeds from 48 trees (24 pendula ideotype and 24 pyramidalis form) were collected to install the Măneciu and Soveja trials. In these trials, at age 25 years, measurements were performed for the following traits: tree height, breast height diameter, crown diameter, number of branches per whorl and dominant branch diameter. Some important traits were calculated: average volume per tree, trees' slenderness, crown slenderness and branches' finesse. Pearson's simple correlations between the analysed traits were calculated and also the correlations between traits and geographic and climatic gradients of provenances' origin. In addition, cores were collected to compare the wood density of the two forms of spruce. In both trials, but especially in the limitative environmental conditions of the Soveja trial, the narrow crowned form of Norway spruce (Picea abies f. pendula) presented more favourable average results than the normal crown spruce form for the most important stand stability traits: trees' slenderness, wood density, branches' diameter and branches' finesse. Between spruce crown forms, in both trials, no significant differences were observed for the growth traits, but between trials, higher results resulted in optimal environmental conditions of the Măneciu test ( $+89 \%$ for the trees' volume). The trees from different provenances and with specific forms of the crown reacted differently to the changing of the testing site, which required the adoption of maximum caution for decisions regarding the transfer of forest reproductive materials. The correlations between the analysed traits converge towards the adoption of a two-step breeding strategy, starting by selection of narrow crowned trees after stability traits.
\end{abstract}

Keywords: abiotic factors; Carpathian forests; ex situ conservation; tree breeding strategy; wood density

\section{Introduction}

For one of the most important conifers of Europe, the Norway spruce (Picea abies (L.) Karst.), recent studies highlight the very important influence of environmental changes to the trees' growth [1-5], with the general trend being acceleration of growth, except for some dry years, when growth has decreased [6,7]. Norway spruce breeding programmes usually aim at selection for climatic adaptation, 
growth and external stem quality [8]. Several studies have found correlations between climate change and wood properties [9-12].

An important trait for analysing the trees' stability is wood density $[13,14]$, which is also considered the most important predictor of wood quality [15]. In conifers, strong relationships between vulnerability to cavitations and wood density were found for most species [16-18]. Important research has concerned Norway spruce wood properties, such as shrinkage, drought sensitivity, hydraulic conductivity and resistance to drill penetration [15,19-24].

In Romania, the Norway spruce represents $77 \%$ of the coniferous forests' surface and $23.2 \%$ of the entire forest surface of the country [25]. In the Romanian Carpathians, the Norway spruce are conserved both in situ in 89 Forest Genetic Resources (FGRs) and 465 seed stands, and ex situ in seed orchards (14) and comparative trials (34) [26,27].

The tree ideotype concept was used for the first time by Karki, in 1985 [28], in Finland, and implemented for the first time in Romania by Enescu, in 1987 [29]. The significance is the one of a perfect tree, distinguished by active growth, superior wood quality and high adaptability. Extensive research has been conducted in relation to the genetic determinism of the crown form, vegetative (especially by cuttings) or generative (where only a half of the descendants inherit the narrow crown character) reproduction, and progeny testing of pendula spruce or hybrids between pendula and pyramidalis (normal crown form), with the most numerous and important studies being conducted in Finland [28,30-32]. The research from Finland indicates some particularities of narrow crowned spruce: low and irregular flowering, the pendula character of branches can be observed around the age of six years when the plants reach a height of $1 \mathrm{~m}$, and in the case of generative multiplication (much cheaper) only a half of the descendants inherit the character. Zubizarreta Gerendiain and collaborators [33,34] draw attention to the plasticity of the narrow crown spruce when increasing the planting distance between seedlings, this variety being indicated especially in the case of dense planting schemes, $1 \mathrm{~m} \times 1 \mathrm{~m}$ or $1 \mathrm{~m} \times 1.5 \mathrm{~m}$, while in a $2 \mathrm{~m} \times 1.5 \mathrm{~m}$ device the pyramidal spruce grow much better (the average volume being double at the age of 20 years). The adoption of more dense planting schemes for narrow crown spruce is the conclusion reached by Kuuluvainen's research [35]. With a dense planting scheme, narrow crowned Norway spruce achieved a very high annual increase in volume without the need for the thinning of stands [3]. Molecular genetic analyses have indicated that the narrow crown type is controlled by a single dominant gene [36], which favours the cloning of this ideotype. The strong genetic control to the crown architecture of Norway spruce was demonstrated in recent research carried out in Germany [37]. In Romania, the research began with a selection of Norway spruce trees with narrow crown (pendula form and columnaris variety) in 25 populations located in all branches of the Romanian Carpathians, most of them being located in the Apuseni Mountains. The cones have been harvested from individuals of spruce with a narrow crown and also from trees which belong to the classic pyramid crown form. In 1994, two half-sib comparative trials were established for the testing of quantitative, qualitative and adaptive traits of narrow crown spruce trees compared with normal crown form ones.

This research aims to analyse the adaptability of the narrow crown spruce (Picea abies pendula form) compared with the classic crown form (pyramidal and wide crown) in two comparative trials. The working hypotheses focused on:

$\checkmark \quad$ Analysis of the main phenotypic traits of growth and the resistance of stem and crown for the two forms of Norway spruce,

$\checkmark$ Comparative analysis of wood density for pendula and pyramidalis Norway spruce crown forms,

$\checkmark$ Influence of the test site using factorial analysis of variance (ANOVA),

$\checkmark$ Analysis of correlations between growth and resistance trait to develop a breeding strategy,

$\checkmark$ Analysing the correlations between tree traits and the geographic and climatic gradients of the provenances' origin place. 


\section{Materials and Methods}

Seeds were harvested from 48 trees (24 pendula and 24 normal crown spruce form, three for each form by each provenance) from eight Norway spruce provenances distributed in three of the four divisions of the Romanian Carpathians (Figure 1, Table 1), and in 1994, two comparative trials of maternal descendants were installed in the Măneciu and Soveja forest districts, both near to the south-east limit of the Eastern Carpathians, the area known in Romania as curvature Carpathians, in the optimal altitude for Norway spruce, in spruce-fir-beech phytoclimatic floor, in B220 provenance region [27].

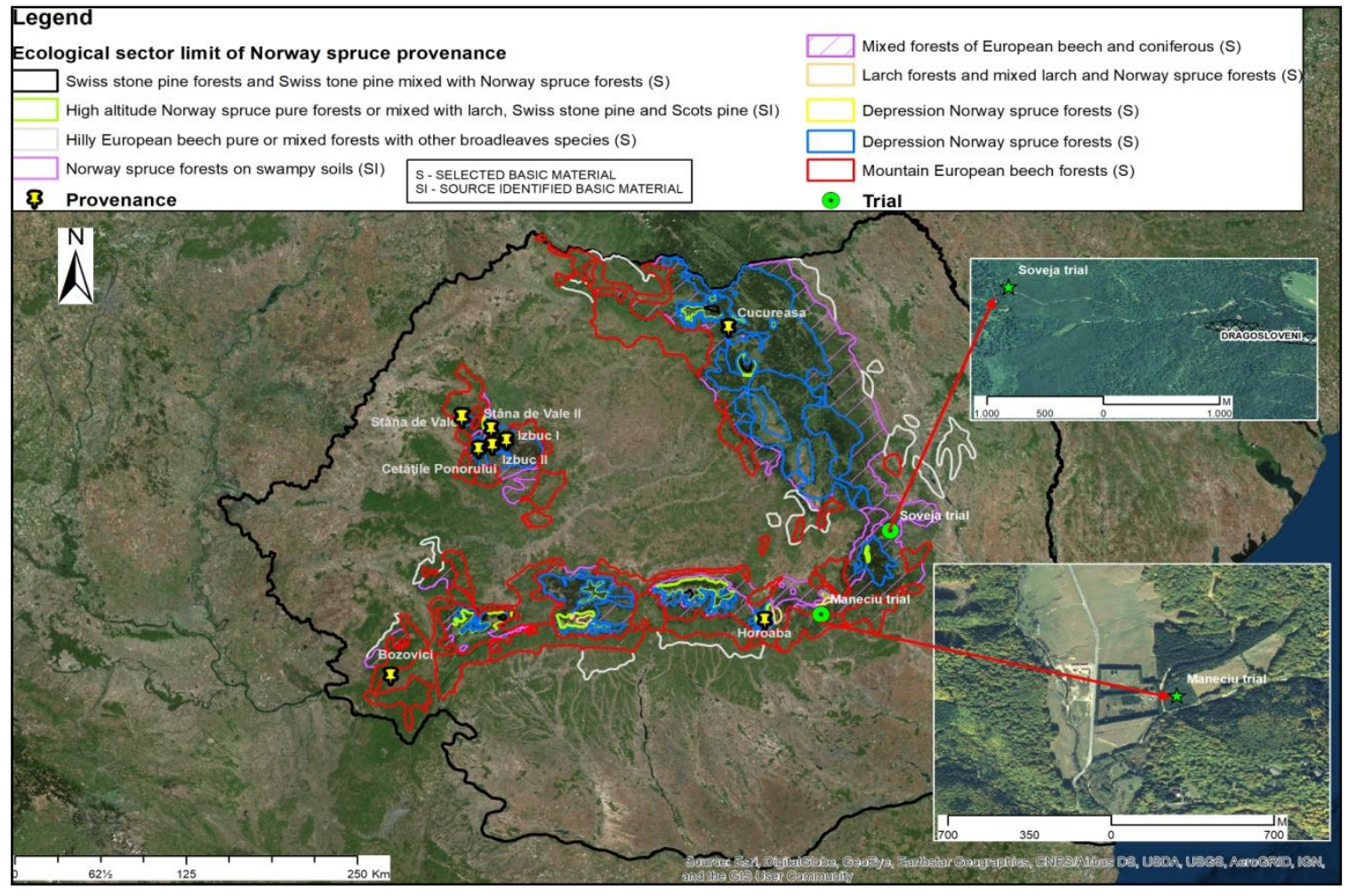

Figure 1. The locations of the field trials and provenances' origin.

Table 1. The location and climatic conditions of the provenances origin place.

\begin{tabular}{|c|c|c|c|c|c|c|c|c|c|}
\hline \multirow{2}{*}{$\begin{array}{c}\text { Provenance } \\
\text { 1. Stâna de Vale I }\end{array}$} & \multirow{2}{*}{$\begin{array}{c}\begin{array}{c}\text { Carpathian } \\
\text { Division }\end{array} \\
\text { WRC, Am }\end{array}$} & \multirow{2}{*}{$\begin{array}{c}\text { Coordinates } \\
\text { (Latitude/Longitude/Altitude) }\end{array}$} & \multirow{2}{*}{$\begin{array}{c}\text { MAT/SAP/AI } \\
4.0^{\circ} \mathrm{C} / 1200 \mathrm{~mm} / 86\end{array}$} & \multicolumn{3}{|c|}{$\begin{array}{l}\text { pendula Spruce } \\
\text { (code in trials) }\end{array}$} & \multicolumn{3}{|c|}{$\begin{array}{l}\text { Common Spruce } \\
\text { (code in trials) }\end{array}$} \\
\hline & & & & 1 & 2 & 3 & 25 & 26 & 27 \\
\hline 2. Stâna de Vale II & WRC, Am & $46^{\circ} 46^{\prime} / 22^{\circ} 36^{\prime} / 1225$ & $4.0^{\circ} \mathrm{C} / 1200 \mathrm{~mm} / 86$ & 4 & 5 & 6 & 28 & 29 & 30 \\
\hline 3. Izbuc I & WRC, Am & $46^{\circ} 36^{\prime} / 22^{\circ} 46^{\prime} / 1200$ & $4.0^{\circ} \mathrm{C} / 1200 \mathrm{~mm} / 86$ & 7 & 8 & 9 & 31 & 32 & 33 \\
\hline 4. Izbuc II & WRC, Am & $46^{\circ} 38^{\prime} / 22^{\circ} 50^{\prime} / 1275$ & $4.0^{\circ} \mathrm{C} / 1200 \mathrm{~mm} / 86$ & 10 & 11 & 12 & 34 & 35 & 36 \\
\hline $\begin{array}{l}\text { 5. Cetăţile } \\
\text { Ponorului }\end{array}$ & WRC, Am & $46^{\circ} 34^{\prime} / 22^{\circ} 42^{\prime} / 1050$ & $4.5^{\circ} \mathrm{C} / 1100 \mathrm{~mm} / 76$ & 13 & 14 & 15 & 37 & 38 & 39 \\
\hline 6. Bozovici & WRC, Bm & $44^{\circ} 57^{\prime} / 21^{\circ} 57^{\prime} / 600$ & $9.5^{\circ} \mathrm{C} / 770 \mathrm{~mm} / 39$ & 16 & 17 & 18 & 40 & 41 & 42 \\
\hline 7. Horoaba & $\mathrm{CC}$ & $45^{\circ} 23^{\prime} / 25^{\circ} 25^{\prime} / 1675$ & $2.8^{\circ} \mathrm{C} / 1200 \mathrm{~mm} / 94$ & 19 & 20 & 21 & 43 & 44 & 45 \\
\hline 8. Cucureasa & $\mathrm{EC}$ & $47^{\circ} 23^{\prime} / 25^{\circ} 04^{\prime} / 935$ & $4.5^{\circ} \mathrm{C} / 960 \mathrm{~mm} / 66$ & 22 & 23 & 24 & 46 & 47 & 48 \\
\hline
\end{tabular}

The Carpathian divisions in Romania: EC = Eastern Carpathians, CC = Curvature Carpathians, Southern Carpathians and WRC = Western Romanian Carpathians (WRC is divided into Banat mountains, Bm, and Apuseni mountains, Am). North latitude, East longitude, altitude, in metres above of the sea level. MAT $=$ mean annual temperature, $\mathrm{SAP}=$ sum of annual precipitations, $\mathrm{AI}=$ De Martonne aridity index. $1-48=$ families code in trials $(1-24=$ pendula, $25-48=$ pyramidalis).

In both trials, the experimental design was an incomplete balanced design, with four replications and 4-12 seedlings per subdivided plots planted at $2 \mathrm{~m}$ by $2 \mathrm{~m}$ spacing, in which each of the eight provenances are represented by descendants obtained from seeds harvested from three pendula and three normal crown spruce trees. The families has a 1-48 code $(1-24=$ pendula, $25-48=$ normal crown 
form). For example, Provenance 1 is represented by families $1-3$ and 25-27, Provenance 2 by $4-6$ and 28-30, etc. (Supplementary Figure S1).

The comparative Soveja trial was located in the forest district Soveja, in the production unit II Soveja, plot 37V on a surface of 0.8 ha. The forest site was 3.3.2.0 (mountain mixed forest of inferior site quality, districambosoils \pm lithic small edaphic with Asperula-Dentaria \pm acidophilous) [38], the natural forest type was mixed coniferous and beech on skeletal soils (medium productivity), the soil type was typical districambosoil, on an undulating medium slope, north exposition, $16^{\circ}$ inclination, at an altitude of $980 \mathrm{~m}$ [39].

The comparative Măneciu trial was located in the forest district Măneciu, in the production unit IV Suzana, plot 69V, on a surface of 1.1 ha. The forest site was 3.3.2.1 (mountain mixed forest of medium site quality, eutricambosoils medium edaphic with Asperula-Dentaria \pm acidophilous) [38], the natural forest type was a normal beech with mull flora, on superior productivity, the soil type was typical eutricambosoil, on a slope with southern exposition, $10^{\circ}$ inclination, at an altitude of $820 \mathrm{~m}$ [40].

At age 25 years (23 years in trials plus two years in the nursery) measurements were made on the main traits of growth, quality and adaptability, as follows:

- $\quad$ Diameter at breast height (Dbh) and diameter at $2.2 \mathrm{~m}$ (D2.2) using a forest calliper;

- $\quad$ Tree height (Th), using a Vertex IV instrument;

- Number of branches per whorl ( $\mathrm{Nbw}$ ) was counted in the whorl situated at $2.2 \mathrm{~m}$ from the ground;

- $\quad$ Crown diameter $(\mathrm{Cd})$, measuring projections of two perpendicular diameters, using a telemeter;

- Dominant branch diameter (Dbd), in whorl situated at $2.2 \mathrm{~m}$ from the ground, measured with electronic callipers;

At the office we also calculated:

- Tree slenderness:

$$
\mathrm{Ts}=\frac{\mathrm{Th}}{\mathrm{Dbh}}
$$

- $\quad$ Trees' volume (Tv), using the regression equation method [41];

- Crown slenderness:

$$
\mathrm{Cs}=\frac{\mathrm{Th}}{\mathrm{C}_{\mathrm{d}}}
$$

- $\quad$ Branches' finesse:

$$
\mathrm{Bf}=\frac{\mathrm{Dbd}}{\mathrm{D}_{2.2}} \times 100
$$

In both comparative trials, from each of the 48 families, four trees were selected (one in each replication) from the average Dbh category, from which cores were taken using a Pressler drill. One hundred and ninety-two cores (96/crown form), plus 15 cores used for moisture content determination, were extracted from a height of $1.30 \mathrm{~m}$ on the level curve. To determine the conventional wood density, a method proposed by Dumitriu-Tătăranu and collaborators [42] and described in detail by Şofletea and collaborators [43], was used. Starting from the apparent density (determined taking into account the humidity of the cores at the time of processing), the density of anhydrous wood was determined. Further, the coefficient of volume swelling was calculated, and finally, the conventional wood density was calculated.

The data were processed using Statistica 10.0 version software [44]. The Kolmogorov-Smirnov test was applied to check the normality of distribution and the assumptions of ANOVA were verified using Levene's test. The total variance was separated in the variance due to replications, provenances, crown forms, families and the variance of error (residual) by applying the ANOVA test, corresponding to the used experimental device [45] and the biological material type.

$$
X_{\mathrm{ijk}}=\mathrm{m}+\alpha_{\mathrm{i}}+\beta_{\mathrm{j}}+\gamma_{\mathrm{k}}+\delta_{1}+\varepsilon_{\mathrm{ijkl}}
$$


where: $m$ is overall average value, $\alpha_{i}$ is component of $i^{\text {th }}$ provenances $(i=1 \ldots \mathrm{a}), \beta_{j}$ is component of $j^{\text {th }}$ replications $(j=1 \ldots b), \gamma_{k}$ is component of $k^{\text {th }}$ groups (crown forms), $\delta_{1}$ is component of $l^{\text {th }}$ families and $\varepsilon_{i j k l}$ is random error affecting $i j k l$ plots.

The population $\times$ location interaction and the influence of test site variation were determined using the bifactorial ANOVA model [45].

$$
x_{i j k}=m+\alpha_{i}+\beta_{j}+\gamma_{k}+\alpha \beta_{i j}+\alpha \gamma_{i k}+\beta \gamma_{j k}+\alpha \beta \gamma_{i j k}+\varepsilon_{i j k}
$$

where: $m, \alpha_{i}$ and $\gamma_{k}$ are as above, $\beta_{j}$ is component of $j^{\text {th }}$ locations $(j=1 \ldots \mathrm{b}), \alpha \beta_{i j}$ is interaction of $i^{\text {th }}$ provenances with $j^{\text {th }}$ locations, $\alpha \gamma_{i k}$ is interaction of $i^{\text {th }}$ provenances with $k^{\text {th }}$ groups, $\beta \gamma_{j k}$ is interaction of $k^{\text {th }}$ groups with $j^{\text {th }}$ locations and $\alpha \beta \gamma_{i j k}$ is the interaction of the all three factors.

The significance level was established with the Fisher $(F)$ test for the transgression probabilities of $5 \%, 1 \%$ and $0.1 \%$.

In addition, Pearson's simple correlations between analysed traits and between traits and geographic and climatic gradients of tested provenances origin were also determined. A very interesting gradient was used, the ecophysiological latitude, introduced by Viersma, in 1962 [46], which corrects the latitude by altitude: one hundred metres difference in altitude is considered equal to a difference of one degree in latitude:

$$
\mathrm{E}_{\mathrm{L}}=\mathrm{L}+\frac{\mathrm{A}}{100}
$$

\section{Results}

\subsection{Trees' Height (Th)}

The limitative environmental conditions from the Soveja trial led to an inferior bioaccumulation capacity in trees from both crown forms compared with the results registered in the Măneciu trial, with average Th being inferior by $29 \%$ (Table 2$)$. This observation is valid also for Dbh (16\% smaller in Soveja) and Tv (47\% smaller in Soveja). The pendula 1-Stâna de Vale I registered the highest Th in the Măneciu trial $(16.6 \mathrm{~m})$ while in the Soveja test the pendula 5-Cetăţile Ponorului was ranked in first place (Figure 2).

Table 2. Mean values ( \pm standard deviation) for phenotypic traits at the crown form level in the

\begin{tabular}{|c|c|c|c|c|c|c|c|c|c|c|c|}
\hline Trial/Crow & n Form & $\begin{array}{l}\text { Number } \\
\text { of Trees }\end{array}$ & $\begin{array}{c}\text { Trees } \\
\text { Height }(\mathrm{m})\end{array}$ & $\begin{array}{l}\text { Breast Height } \\
\text { Diameter }(\mathrm{cm})\end{array}$ & $\begin{array}{c}\text { Trees' } \\
\text { Volume } \\
\left(\mathrm{m}^{3}\right)\end{array}$ & $\begin{array}{c}\text { Trees' } \\
\text { Slenderness } \\
\text { (Th/Dbh) }\end{array}$ & $\begin{array}{l}\text { Crown } \\
\text { Diameter } \\
(\mathrm{m})\end{array}$ & $\begin{array}{l}\text { Crown } \\
\text { Slenderness } \\
(\mathrm{Th} / \mathrm{Cd})\end{array}$ & $\begin{array}{c}\text { No. of } \\
\text { Branches/Whorl }\end{array}$ & $\begin{array}{c}\text { Branches' } \\
\text { Diameter } \\
(\mathrm{mm})\end{array}$ & $\begin{array}{c}\text { Branches' } \\
\text { Finesse (\%) }\end{array}$ \\
\hline \multirow{3}{*}{ Măneciu } & pendula & 960 & \pm 2.1 & .7 & $0.211 \pm 0.1$ & $97 \pm 12$ & $2.4 \pm 0.5$ & $6.8 \pm 0.9$ & $6.1 \pm 0.7$ & $21.4 \pm 4.6$ & $12.6 \pm 0.8$ \\
\hline & normal & 960 & $16.2 \pm 2.0$ & $17.0 \pm 3.6$ & $0.210 \pm 0.1$ & $97 \pm 12$ & $2.6 \pm 0.6$ & $6.3 \pm 0.9$ & $6.1 \pm 0.7$ & $22.1 \pm 4.8$ & $12.9 \pm 0.8$ \\
\hline & Average & 1920 & $16.2 \pm 2.1$ & $17.0 \pm 3.6$ & $0.210 \pm 0.1$ & $97 \pm 12$ & $2.5 \pm 0.5$ & $6.6 \pm 0.7$ & $6.1 \pm 0.7$ & $21.7 \pm 4.7$ & $12.8 \pm 0.8$ \\
\hline \multirow{3}{*}{ Soveja } & pendula & 435 & $11.6 \pm 1.7$ & $14.5 \pm 3.4$ & $0.113 \pm 0.1$ & $82 \pm 12$ & $3.1 \pm 0.8$ & $4.0 \pm 1.1$ & $7.2 \pm 0.8$ & $20.0 \pm 3.8$ & $14.2 \pm 2.7$ \\
\hline & normal & 387 & $11.5 \pm 1.9$ & $14.1 \pm 3.7$ & $0.108 \pm 0.1$ & $84 \pm 13$ & $3.0 \pm 0.8$ & $4.0 \pm 1.0$ & $7.2 \pm 0.9$ & $20.2 \pm 4.1$ & $14.9 \pm 3.1$ \\
\hline & Average & 822 & $11.5 \pm 1.8$ & $14.3 \pm 3.5$ & $0.111 \pm 0.1$ & $83 \pm 13$ & $3.1 \pm 0.8$ & $4.0 \pm 1.0$ & $7.2 \pm 0.8$ & $20.1 \pm 3.9$ & $14.5 \pm 2.9$ \\
\hline
\end{tabular}
Măneciu and Soveja trials (significant differences between forms are in bold).

The Th results highlight a very good homogeneity, only two groups of families in Soveja and three in Măneciu are missing from the first homogeneous group. ANOVA (Supplementary Table S1) revealed no significant differences between Norway spruce crown forms (F) but highly significant influences $(p<0.001)$ of provenances and replications. In the Soveja trial, the family factor also plays a significant role.

Factorial ANOVA (Table 3) showed a highly significant influence $(p<0.001)$ of the testing site (L), provenance $(\mathrm{P})$ and their interaction $(\mathrm{L} \times \mathrm{P})$, which suggests a different reaction of provenances to the changing of the environmental conditions. One provenance, 5-Cetăţile Ponorului, ranked high in both trials, for both crown forms (P5 and N5). When comparing the two forms of spruce crown at the level of each provenance, a slight superiority of the pendula spruce was found within the Provenances 1,2 , 7 and 8 in the Măneciu trial and 1,2,5 and 6 in the Soveja test (Figure 2), the first two provenances had superior Th for pendula in both trials. 


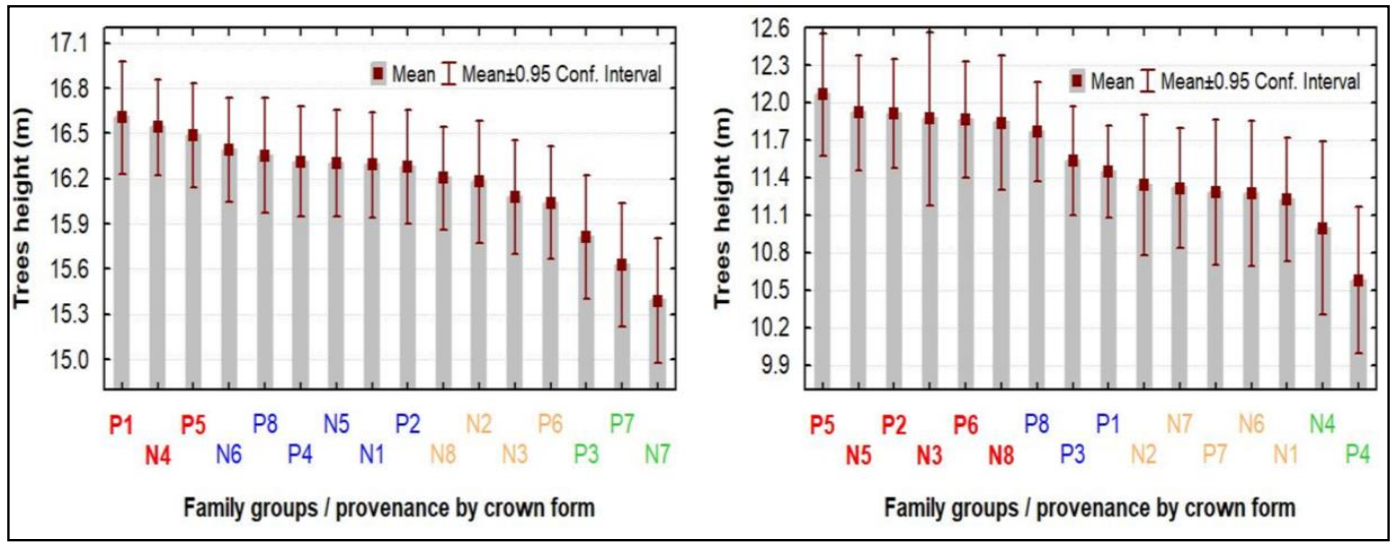

Figure 2. Distribution of family groups for trees' height in the Măneciu (left) and Soveja (right) trials. The first homogeneous group (most important for the breeding programme) is composed by the first three groups of collared families. Significant differences were registered between red and green groups, blue and the last two families groups (P7 and N7 in Măneciu, N4 and P4 in Soveja) and orange toward the last one families group (N7 and P4 in Măneciu and Soveja, respectively).

Table 3. Influence of testing site, provenance and crown form of Norway spruce.

\begin{tabular}{|c|c|c|c|c|c|c|c|c|c|c|c|}
\hline Trait & Factor & DF & SS & MS & $F$ & $p$ & Trait & SS & MS & $F$ & $p$ \\
\hline \multirow{8}{*}{ Trees' height } & Locality (L) & 1 & $12,336.1$ & $12,336.1$ & 3115.9 & 0.000 & \multirow{8}{*}{$\mathrm{Tv}$} & 5.7152 & 5.7152 & 672.28 & 0.000 \\
\hline & Form $(\mathrm{F})$ & 1 & 1.5 & 1.5 & 0.4 & 0.544 & & 0.0035 & 0.0035 & 0.412 & 0.521 \\
\hline & Provenance $(\mathrm{P})$ & 7 & 117.4 & 16.8 & 4.2 & 0.000 & & 0.1226 & 0.0175 & 2.061 & 0.045 \\
\hline & $\mathrm{L} \times \mathrm{F}$ & 1 & 0.6 & 0.6 & 0.2 & 0.695 & & 0.0022 & 0.0022 & 0.253 & 0.615 \\
\hline & $\mathrm{L} \times \mathrm{P}$ & 7 & 111.6 & 15.9 & 4.0 & 0.000 & & 0.0561 & 0.0080 & 0.943 & 0.472 \\
\hline & $\mathrm{F} \times \mathrm{P}$ & 7 & 28.6 & 4.1 & 1.0 & 0.406 & & 0.0332 & 0.0047 & 0.558 & 0.790 \\
\hline & $\mathrm{L} \times \mathrm{F} \times \mathrm{P}$ & 7 & 22.3 & 3.2 & 0.8 & 0.584 & & 0.0658 & 0.0094 & 1.105 & 0.357 \\
\hline & Error & 2710 & $10,729.1$ & 4.0 & & & & 23.0383 & 0.0085 & & \\
\hline \multirow{8}{*}{$\begin{array}{l}\text { Breast height } \\
\text { diameter }\end{array}$} & Locality (L) & 1 & 4267.9 & 4267.9 & 329.65 & 0.000 & \multirow{8}{*}{ Ts } & 109,979 & 109,979 & 755.6 & 0.000 \\
\hline & Form $(\mathrm{F})$ & 1 & 21.0 & 21.0 & 1.63 & 0.202 & & 524 & 524 & 3.6 & 0.058 \\
\hline & Provenance(P) & 7 & 273.9 & 39.1 & 3.02 & 0.004 & & 1696 & 242 & 1.7 & 0.113 \\
\hline & $\mathrm{L} \times \mathrm{F}$ & 1 & 25.6 & 25.6 & 1.98 & 0.159 & & 906 & 906 & 6.2 & 0.013 \\
\hline & $\mathrm{L} \times \mathrm{P}$ & 7 & 128.3 & 18.3 & 1.42 & 0.194 & & 929 & 133 & 0.9 & 0.496 \\
\hline & $\mathrm{F} \times \mathrm{P}$ & 7 & 44.1 & 6.3 & 0.49 & 0.845 & & 1196 & 171 & 1.2 & 0.314 \\
\hline & $\mathrm{L} \times \mathrm{F} \times \mathrm{P}$ & 7 & 126.3 & 18.0 & 1.39 & 0.204 & & 2733 & 390 & 2.7 & 0.009 \\
\hline & Error & 2710 & $35,085.8$ & 12.9 & & & & 394,453 & 146 & & \\
\hline \multirow{8}{*}{$\begin{array}{l}\text { Crown } \\
\text { diameter }\end{array}$} & Locality (L) & 1 & 152.88 & 152.88 & 376.57 & 0.000 & \multirow{8}{*}{ Cs } & 3706.45 & 3706.45 & 4313.2 & 0.000 \\
\hline & Form $(\mathrm{F})$ & 1 & 2.87 & 2.87 & 7.06 & 0.008 & & 30.82 & 30.82 & 35.87 & 0.000 \\
\hline & Provenance $(\mathrm{P})$ & 7 & 13.01 & 1.86 & 4.58 & 0.000 & & 14.31 & 2.04 & 2.38 & 0.020 \\
\hline & $\mathrm{L} \times \mathrm{F}$ & 1 & 6.69 & 6.69 & 16.47 & 0.000 & & 30.62 & 30.62 & 35.63 & 0.000 \\
\hline & $\mathrm{L} \times \mathrm{P}$ & 7 & 11.43 & 1.63 & 4.02 & 0.000 & & 20.10 & 2.87 & 3.34 & 0.002 \\
\hline & $\mathrm{F} \times \mathrm{P}$ & 7 & 5.37 & 0.77 & 1.89 & 0.067 & & 15.25 & 2.18 & 2.54 & 0.013 \\
\hline & $\mathrm{L} \times \mathrm{F} \times \mathrm{P}$ & 7 & 5.76 & 0.82 & 2.03 & 0.048 & & 17.14 & 2.45 & 2.85 & 0.006 \\
\hline & Error & 2710 & 1100.17 & 0.41 & & & & 2328.76 & 0.86 & & \\
\hline \multirow{8}{*}{$\begin{array}{l}\text { Number of } \\
\text { branches } \\
\text { per whorl }\end{array}$} & Locality (L) & 1 & 612.4 & 612.4 & 1235.4 & 0.000 & \multirow{8}{*}{ Dbd } & 1462.3 & 1462.3 & 74.07 & 0.000 \\
\hline & Form (F) & 1 & 0.1 & 0.1 & 0.2 & 0.673 & & 133.6 & 133.6 & 6.77 & 0.009 \\
\hline & Provenance $(\mathrm{P})$ & 7 & 28.0 & 4.0 & 8.1 & 0.000 & & 447.4 & 63.9 & 3.24 & 0.002 \\
\hline & $\mathrm{L} \times \mathrm{F}$ & 1 & 0.6 & 0.6 & 1.2 & 0.275 & & 20.6 & 20.6 & 1.04 & 0.308 \\
\hline & $\mathrm{L} \times \mathrm{P}$ & 7 & 11.9 & 1.7 & 3.4 & 0.001 & & 659.2 & 94.2 & 4.77 & 0.000 \\
\hline & $\mathrm{F} \times \mathrm{P}$ & 7 & 10.4 & 1.5 & 3.0 & 0.004 & & 135.6 & 19.4 & 0.98 & 0.443 \\
\hline & $\mathrm{L} \times \mathrm{F} \times \mathrm{P}$ & 7 & 7.8 & 1.1 & 2.3 & 0.028 & & 206.2 & 29.5 & 1.49 & 0.165 \\
\hline & Error & 2710 & 1343.4 & 0.5 & & & & $53,498.6$ & 19.7 & & \\
\hline \multirow{8}{*}{$\begin{array}{l}\text { Branches' } \\
\text { finesse }\end{array}$} & Locality (L) & 1 & 1862.5 & 1862.5 & 639.4 & 0.000 & \multirow{8}{*}{ Cwd } & 0.00343 & 0.00343 & 1.73 & 0.189 \\
\hline & Form $(\mathrm{F})$ & 1 & 174.3 & 174.3 & 59.8 & 0.000 & & 0.00295 & 0.00295 & 1.49 & 0.223 \\
\hline & Provenance $(\mathrm{P})$ & 7 & 152.3 & 21.8 & 7.5 & 0.000 & & 0.13897 & 0.01985 & 10.03 & 0.000 \\
\hline & $\mathrm{L} \times \mathrm{F}$ & 1 & 20.6 & 20.6 & 7.1 & 0.008 & & 0.00091 & 0.00091 & 0.46 & 0.499 \\
\hline & $\mathrm{L} \times \mathrm{P}$ & 7 & 175.6 & 25.1 & 8.6 & 0.000 & & 0.14795 & 0.02114 & 10.68 & 0.000 \\
\hline & $\mathrm{F} \times \mathrm{P}$ & 7 & 46.9 & 6.7 & 2.3 & 0.024 & & 0.05375 & 0.00768 & 3.88 & 0.000 \\
\hline & $\mathrm{L} \times \mathrm{F} \times \mathrm{P}$ & 7 & 51.3 & 7.3 & 2.5 & 0.014 & & 0.05687 & 0.00812 & 4.10 & 0.000 \\
\hline & Error & 2710 & 7893.4 & 2.9 & & & & 0.69690 & 0.00198 & & \\
\hline
\end{tabular}

$\mathrm{DF}=$ Degrees of freedom (for Cwd error is 352), SS = sum of squares, MS = mean squares, $F$-values, $p<0.05$ is significant, $p<0.01$ is distinctly significant, $p<0.001$ is highly significant (bold). Tv $=$ trees' $^{\prime}$ volume, Ts $=$ trees' $^{\prime}$ slenderness, $\mathrm{Cs}=$ crown slenderness, $\mathrm{Dbd}=$ dominant branch diameter, $\mathrm{Cwd}=$ conventional wood density. 


\subsection{Breast Height Diameter (Dbh)}

Although, in the Măneciu trial, established in optimal environmental conditions, there were no differences between the two forms of spruce crown, in the limitative environmental conditions of the Soveja test, the pendula spruce was adapted much better, with Dbh being superior by $3 \%$ (statistically insignificant but very close to the significance threshold) and within provenances, six of the eight groups of pendula families recorded values higher than pyramidal spruce, the largest difference $(9 \%)$ being recorded within the 6-Bozovici provenance. For both spruce crown forms, intra-tree variation was double for Dbh compared with Th in Soveja and 75\% higher in the Măneciu trial (Table 2). Factorial ANOVA (Table 3) have the same meaning as for Th, except for the $\mathrm{L} \times \mathrm{P}$ interaction, which is insignificant for Dbh.

\subsection{Trees' Volume (Tv)}

For $\mathrm{Tv}$, the descendants of pendula spruce registered a mean value $\left(0.211 \mathrm{~m}^{3}\right.$ in the Măneciu and $0.113 \mathrm{~m}^{3}$ in the Soveja trials) slightly higher (1\% and 5\%, respectively) than the normal crown spruce families, but the differences were statistically insignificant (Table 2). A significant influence of provenance and highly significant influence of testing site were highlighted by factorial ANOVA (Table 3). Inside each provenance, a slight superiority of the pendula spruce was registered within the Provenances 1, 2, 7 and 8 in the Măneciu trial and 1,2, 5, 6 and 8 in the Soveja trial.

\subsection{Trees' Slenderness (Ts)}

Trees' slenderness (Ts), calculated as the ratio of tree height and Dbh, is a very important indicator of the stability of Norway spruce forests; Popa [47] determined an optimal value of Ts (80) and a limit value of Ts (100), above which the stand's stability against wind and snow is endangered.

In the Măneciu trial, the average value of Ts observed for all 960 pendula trees was 97 , the same average value registered for normal crown trees. In the Soveja trial, the average value of Ts observed for all 435 pendula trees was 82 , which is distinctly significantly lower $(p=0.007)$ than the average value registered for the trees of pyramidalis spruce form (Table 2). These results indicate an adaptive reaction of Norway spruce (especially the pendula form) to worsening of environmental conditions. In the Soveja test, lower values for Ts (favourable to wind and snow resistance) were observed for almost all pendula families (equality between the two forms inside the first and second provenances), with exception of the provenance originating from the highest altitude, 7-Horoaba, within which Ts was lower by $2 \%$ for pyramidalis trees. In both trials ANOVA (Supplementary Table S1) showed a significant influence $(p<0.01)$ of family. Factorial ANOVA (Table 3) showed a highly significant influence $(p<0.001)$ of the testing site, a distinctly significant influence $(p<0.01)$ of $\mathrm{L} \times \mathrm{F} \times \mathrm{P}$, and a significant influence $(p<0.05)$ of $\mathrm{L} \times \mathrm{F}$, which suggests a different and favourable reaction of pendula families to the change in environmental conditions.

\subsection{Crown Diameter ( $C d$ ) and Crown Slenderness (Cs)}

Crown diameter is the most important trait to promote the narrow crowned form of Norway spruce. In the Măneciu trial, where the competition for light was much stronger, the pendula trees registered an average value of Cd significantly smaller (favourable) than pyramidalis spruce trees (Table 2), the two forms of spruce crown being completely separated one from another, according to Duncan's test (Figure 3) and cluster analysis (Figure 4).

In Duncan's test, all pendula provenances are included in the first homogeneous group, being susceptible to selection in the next generation of the breeding programme. In cluster analysis, all pendula are included in Cluster 2 and more than that, the provenances from the Apuseni Mountains are all included in the second sub-cluster (Figure 4).

Diagram for crown traits, complete linkage, Euclidean distances. 


\begin{tabular}{|c|c|c|c|c|c|c|c|c|c|c|c|c|c|c|}
\hline F/P & $\begin{array}{c}\text { Crown } \\
\text { diameter }\end{array}$ & \multicolumn{6}{|c|}{$\mathrm{Hg}, \alpha=5 \%$} & F/P & $\begin{array}{l}\text { Crown } \\
\text { diameter }\end{array}$ & \multicolumn{5}{|c|}{$\mathrm{Hg}, \alpha=5 \%$} \\
\hline P3 & 2.37 & 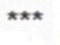 & & & & & & N4 & 2.62 & $\star \star \star \star$ & & & & \\
\hline P8 & 2.42 & 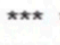 & $\star \star \star \star$ & & & & & $\mathrm{P} 4$ & 2.81 & $\star \star \star \star$ & $\star \star \star \star$ & & & \\
\hline P4 & 2.42 & $\star * \star *$ & $\star \star \star \star$ & $\star \star \star \star$ & & & & P7 & 2.86 & $\star \star \star \star$ & $\star \star \star \star \star \star$ & 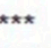 & & \\
\hline $\mathrm{P} 2$ & 2.43 & $\star \star \star \star$ & 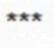 & $\star \star \star *$ & $\star * \star *$ & & & P3 & 2.96 & $\star \star \star \star$ & $\star * * * *$ & 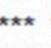 & $\star \star \star \star$ & \\
\hline P5 & 2.44 & $\star \star \star \star$ & $\star \star \star \star$ & $\star \star \star \star \star$ & $\star \star \star \star$ & & & N1 & 2.99 & & $\star \star \star \star \star *$ & 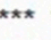 & 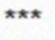 & $\star \star \star$ \\
\hline P6 & 2.45 & $\star \star \star \star *$ & 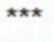 & $\star \star \star \star *$ & 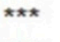 & & & $\mathrm{P} 2$ & 2.99 & & $\star \star \star \star *$ & 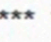 & $\star \star \star \star$ & $\star \star \star$ \\
\hline P7 & 2.46 & $\star \star \star \star *$ & $\star \star \star \star *$ & $\star \star \star \star$ & 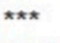 & & & N7 & 3.01 & & $\star \star \star \star *$ & $\star \star \star \star$ & 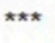 & $\star \star \star \star$ \\
\hline P1 & 2.49 & $\star \star \star \star$ & 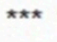 & $\star \star \star *$ & $\star \star \star \star *$ & $\star \star \star \star$ & & N5 & 3.06 & & 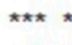 & $\star \star \star \star$ & $\star \star \star \star$ & $\star \star \star \star$ \\
\hline N1 & 2.55 & & $\star \star \star \star$ & $\star \star * *$ & $\star * \star *$ & $\star \star \star \star *$ & $\star \star \star \star$ & P8 & 3.07 & & $\star \star \star \star \star *$ & $\star \star * \star$ & $\star \star \star \star$ & 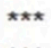 \\
\hline N8 & 2.58 & & $\star \star \star \star$ & $\star \star \star \star *$ & $\star \star \star \star$, & $\star \star \star \star$ & $\star \star \star \star$ & N6 & 3.09 & & $\star \star \star \star \star *$ & 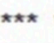 & $\star \star \star \star$ & 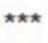 \\
\hline N3 & 2.58 & & & $\star \star \star *$, & $\star * * *$ & $\star \star \star \star$, & $\star \star * \star$ & N2 & 3.09 & & $* * * *$ & $\star \star \star \star$ & $\star \star \star \star$ & $\star \star \star *$ \\
\hline N7 & 2.59 & & & & $\star \star \star \star$, & $\star \star \star \star$, & 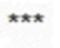 & N8 & 3.15 & & 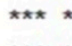 & $\star \star \star \star$ & $\star \star \star \star$ & $\star \star \star \star$ \\
\hline N2 & 2.64 & & & & & $\star \star \star \star x$ & 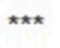 & P1 & 3.19 & & 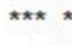 & 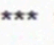 & $\star \star \star \star$ & 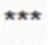 \\
\hline N4 & 2.65 & & & & & $\star \star \star \star *$ & $\star \star \star \star$ & N3 & 3.20 & & & 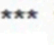 & $\star \star \star \star$ & $\star \star \star \star$ \\
\hline N5 & 2.67 & & & & & & $\star \star \star \star *$ & P5 & 3.28 & & & & $\star \star \star \star$ & 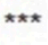 \\
\hline N6 & 2.69 & & & & & & $\star \star \star \star *$ & P6 & 3.35 & & & & & $\star \star * \star$ \\
\hline
\end{tabular}

Figure 3. Duncan's test for crown diameter in the Măneciu (left) and Soveja (right) trials. Homogeneous groups $(\mathrm{Hg})$ for $\alpha=5 \%$.

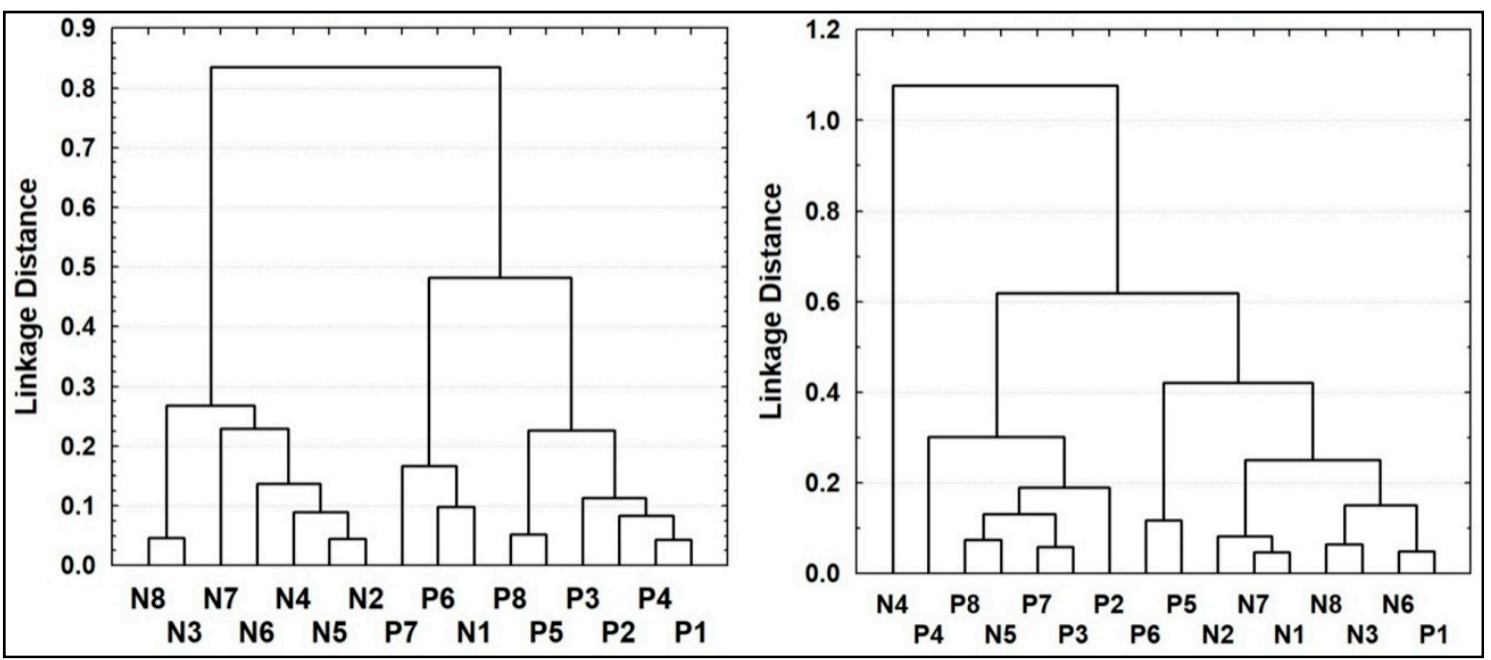

Figure 4. Cluster analysis for crown traits in the Măneciu (left) and Soveja (right) trials.

In the first homogeneous group, three narrow crowned provenances are included but the first one belongs to the normal crown form (Figure 3). Once again, the P3, P4 and P7 registered small values for $\mathrm{Cd}$, being susceptible for selection in the next generation. In the opposite situation, the P5 and P6 narrow crowned provenances were ranked in the last positions in the Soveja test (Figure 3).

In the limitative conditions of the Soveja trial, where the competition for light was reduced, the Dbh and $\mathrm{Cd}$ developed better (although Dbh was smaller by $16 \%$, the value was acceptable compared with Th, lower by $29 \%$ in Soveja), average value for Cd being higher by $24 \%$ than the one registered in the Măneciu trial (Table 2). Regarding the provenances' stability, the very high value registered for Cd in the Soveja trial was balanced by crown slenderness (Cs), a trait that was lower by $39 \%$ (41\% between pendula trees) than in the Măneciu test (Table 2). Although, in the Măneciu trial, Cs registered the lowest values for the provenance that originated from the highest altitude (7-Horoaba), for both crown forms of spruce, in Soveja, the same provenance registered the highest values for pendula trees and one of the highest for normal crown trees.

ANOVA underlined a significant influence of crown form factor only in the Măneciu trial (for both traits, Table 1, Supplementary Table S1), while factorial ANOVA (Table 3) indicated a significant 
influence of almost all factors (except the $\mathrm{P} \times \mathrm{F}$ interaction for $\mathrm{Cd}$ ) suggesting a different reaction of provenances and crown forms in Norway spruce to the change in the environmental conditions.

\subsection{Branches' Characteristics}

The average value for the number of branches per whorl (Nbw) was 15\% lower in the Măneciu test; in both trials, the result did not differ between Norway spruce crown forms (Table 2), significant influences (Supplementary Table S1) having the provenances (in both trials) and families (only in Soveja trial). Factorial ANOVA underlined a highly significant $(p<0.001)$ influence of testing site and provenance, and also of crown form within the provenance (Table 3 ).

In the limitative conditions of the Soveja trial, branches' diameter (Dbd) was lower by $7 \%$, while the branches' finesse (Bf, reporting Dbd to trunk diameter) was higher by $13 \%$ than in the Măneciu trial (Table 2). In the Soveja test, Dbd was lower only with $1 \%$ for pendula compared with normal crown trees, while in the Măneciu test the difference (3\%), also favourable to pendula trees, was statistically significant. The $\mathrm{Bf}$ was also favourable to pendula trees, the average value being lower (statistically significant) than the value registered for normal crown trees with $2 \%$ and $5 \%$ in the Măneciu and Soveja trials, respectively (Table 2). Inside the provenances, in the Măneciu trial, the pendula trees registered lower values (more favourable) in all provenances for Bf and in seven of eight provenances (except Stâna de Vale I) for Dbd. ANOVA (Supplementary Table S1) underlined a highly significant influences of family factor for both traits, in Măneciu trial. In the Soveja comparative trial, almost the same result was registered for Bf (except Stâna de Vale I), while Dbd values were lower for pendula only in four provenances. For both traits and in both trials, the pendula trees from 3-Izbuc I provenances registered the most favourable results. Factorial ANOVA (Table 3) revealed a significant influence of all factors to $\mathrm{Bf}$, while for Dbd the factors interactions (except $\mathrm{L} \times \mathrm{P}$ ) had an insignificant influence.

\subsection{Conventional Wood Density (Cwd)}

In the Măneciu test, the average value for Cwd was $0.365 \mathrm{~g} / \mathrm{cm}^{3}$, the descendants of narrow crowned trees registered an average value $\left(0.366 \mathrm{~g} / \mathrm{cm}^{3}\right)$ greater by only $1 \%$ (statistically insignificant) than the average values registered for the trees reported as the normal crown form of Norway spruce. Inside provenances, Cwd was higher for narrow crowned trees in five of the eight provenances (Figure 5).
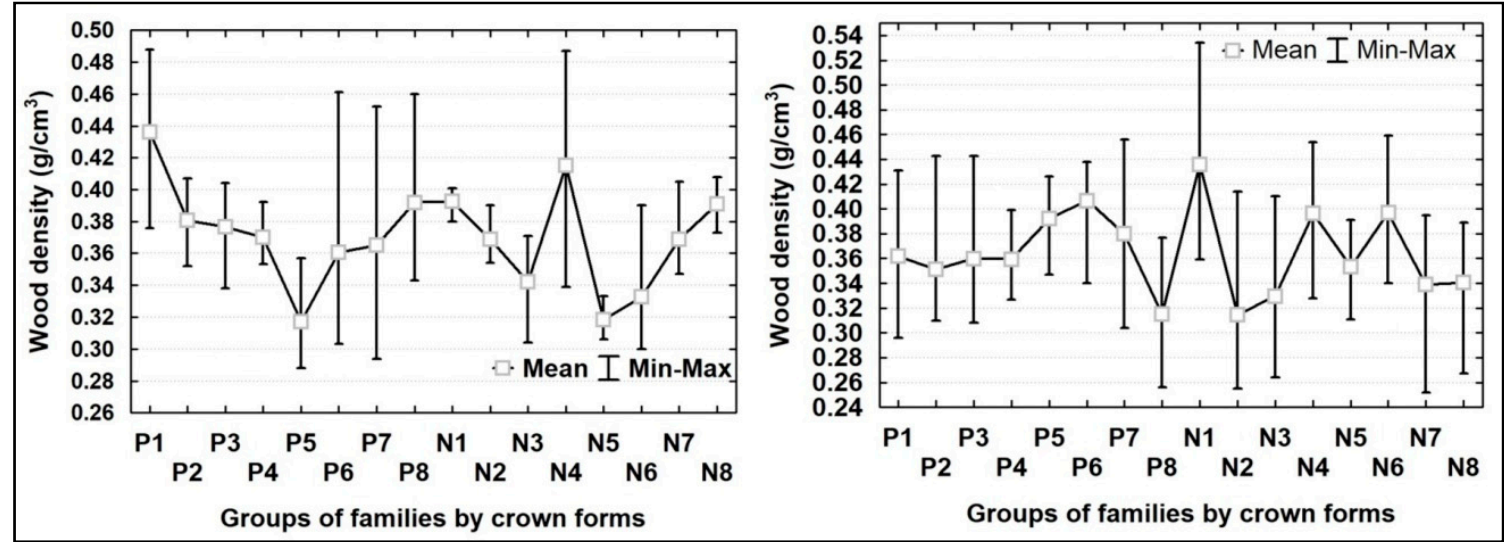

Figure 5. Conventional wood density in the Măneciu (left) and Soveja (right) trials.

In the Soveja trial, the mean value for Cwd was $0.371 \mathrm{~g} / \mathrm{cm}^{3}$, the descendants of narrow crowned trees registered an average value $\left(0.375 \mathrm{~g} / \mathrm{cm}^{3}\right)$ greater by only $2.5 \%$ (statistically insignificant) than the average values registered for the trees reported as the normal crown form of Norway spruce. Inside provenances, Cwd was higher for narrow crowned trees in five of the eight provenances, while in another two provenances the results for the two crown forms were almost equal (Figure 5). Only inside 
4-Izbuc II provenance are the Cwd higher for normal crown trees. The pendula descendants from Provenances 2, 3 and 6, showed superior Cwd compared with normal crown trees in both trials. In the limitative environmental conditions of the Soveja trial, a very high homogeneity was registered inside the 2-Stâna de Vale II and 3-Izbuc I provenances, for both crown forms, an opposite tendency being registered for provenance 6-Bozovici (Figure 5).

Only the provenance factor played a highly significant role in the results obtained for Cwd (Table 3), while the locality factor, which highly influenced all the phenotypic traits, had an insignificant influence.

\subsection{Correlations}

In both trials, positive and in general highly significant correlations were found between growth traits without any significant differences between the two Norway spruce crown forms (Table 4). Positive and significant correlations resulted between growth traits and qualitative/stability traits $(\mathrm{Nbw}, \mathrm{Cd}, \mathrm{Dbd})$. Although, in the trial established in optimal environmental conditions (Măneciu), the negative correlations between Bf and growth traits (significant only for pendula trees) had a low value, in the limitative conditions of the Soveja trial the size of correlations was six times higher for both forms of Norway spruce. The negative and highly significant correlations between growth traits and trees' slenderness (Ts) were more intense in the Măneciu trial than in Soveja and were under the strong influence of Dbh (Table 4). In addition, favourable correlations for trials' stability were registered between Ts and Cs.

Table 4. Correlations between analysed traits and between traits and geographic and climatic gradients of provenances' origin at crown form level (pendula up to - and pyramidalis, down to -).

\begin{tabular}{|c|c|c|c|c|c|c|c|c|c|c|c|c|c|c|}
\hline \multicolumn{15}{|c|}{ Măneciu Trial } \\
\hline Variables & Dbh & Th & $\mathbf{T v}$ & Ts & $\mathrm{Cd}$ & Cs & Nbw & Dbd & Bf & N Lat & N Lc & E Lo & Alt & AI \\
\hline Dbh & - & 0.88 & 0.98 & -0.85 & 0.87 & -0.48 & 0.44 & 0.96 & -0.11 & 0.07 & 0.01 & -0.02 & -0.02 & 0.01 \\
\hline Th & 0.88 & - & 0.88 & -0.55 & 0.76 & -0.22 & 0.41 & 0.85 & -0.10 & 0.09 & -0.03 & -0.05 & -0.05 & -0.01 \\
\hline Tv & 0.98 & 0.88 & - & -0.79 & 0.85 & -0.43 & 0.43 & 0.93 & -0.13 & 0.07 & 0.01 & -0.02 & -0.01 & 0.02 \\
\hline Ts & -0.85 & -0.52 & -0.77 & - & -0.74 & 0.62 & -0.37 & -0.83 & 0.04 & -0.05 & -0.01 & 0.01 & 0.00 & -0.02 \\
\hline $\mathrm{Cd}$ & 0.87 & 0.77 & 0.85 & -0.72 & - & -0.78 & 0.40 & 0.82 & -0.13 & -0.02 & 0.00 & 0.00 & 0.00 & -0.01 \\
\hline Cs & -0.55 & -0.29 & -0.51 & 0.68 & -0.81 & - & -0.23 & -0.45 & 0.08 & 0.09 & -0.02 & -0.04 & -0.05 & -0.01 \\
\hline Nbw & 0.52 & 0.46 & 0.51 & -0.46 & 0.44 & -0.27 & - & 0.40 & -0.11 & 0.04 & 0.07 & 0.03 & 0.06 & 0.07 \\
\hline Dbd & 0.96 & 0.86 & 0.94 & -0.81 & 0.84 & -0.52 & 0.51 & - & 0.17 & 0.06 & -0.02 & -0.02 & -0.04 & -0.02 \\
\hline Bf & 0.00 & 0.05 & -0.03 & 0.03 & 0.01 & 0.02 & 0.04 & 0.26 & - & -0.04 & -0.07 & 0.01 & -0.06 & -0.08 \\
\hline N Lat & 0.01 & 0.05 & 0.01 & 0.03 & -0.03 & 0.09 & 0.00 & 0.03 & 0.11 & & & & & \\
\hline N Lc & -0.06 & -0.09 & -0.06 & 0.03 & -0.05 & 0.00 & 0.05 & -0.07 & -0.03 & & & & & \\
\hline E Lo & -0.07 & -0.11 & -0.07 & -0.01 & -0.04 & -0.04 & -0.04 & -0.08 & -0.07 & & & & & \\
\hline Alt & -0.07 & -0.11 & -0.06 & 0.02 & -0.04 & -0.02 & 0.05 & -0.08 & -0.06 & & & & & \\
\hline AI & -0.05 & -0.07 & -0.04 & 0.03 & -0.04 & 0.02 & 0.06 & -0.06 & -0.02 & & & & & \\
\hline \multicolumn{15}{|c|}{ Soveja Trial } \\
\hline Variables & Dbh & Th & Tv & Ts & $\mathrm{Cd}$ & Cs & $\mathrm{Nbw}$ & Dbd & Bf & N Lat & N Lc & E Lo & Alt & AI \\
\hline Dbh & - & 0.81 & 0.97 & -0.81 & 0.79 & -0.45 & 0.41 & 0.74 & -0.64 & -0.03 & -0.14 & -0.06 & -0.14 & -0.13 \\
\hline Th & 0.83 & - & 0.83 & -0.36 & 0.67 & -0.23 & 0.40 & 0.55 & -0.63 & 0.00 & -0.11 & -0.03 & -0.12 & -0.10 \\
\hline $\mathbf{T v}$ & 0.97 & 0.83 & - & -0.70 & 0.77 & -0.39 & 0.36 & 0.72 & -0.57 & -0.03 & -0.13 & -0.06 & -0.14 & -0.13 \\
\hline Ts & -0.82 & -0.40 & -0.73 & - & -0.62 & 0.52 & -0.30 & -0.63 & 0.48 & 0.04 & 0.11 & 0.06 & 0.11 & 0.11 \\
\hline $\mathrm{Cd}$ & 0.82 & 0.76 & 0.78 & -0.62 & - & -0.80 & 0.35 & 0.71 & -0.37 & -0.06 & -0.17 & -0.10 & -0.16 & -0.15 \\
\hline Cs & -0.50 & -0.33 & -0.42 & 0.56 & -0.82 & - & -0.24 & -0.51 & 0.06 & 0.03 & 0.12 & 0.11 & 0.12 & 0.10 \\
\hline Nbw & 0.48 & 0.47 & 0.45 & -0.34 & 0.45 & -0.26 & - & 0.21 & -0.38 & 0.14 & 0.07 & 0.04 & 0.03 & 0.08 \\
\hline Dbd & 0.74 & 0.54 & 0.70 & -0.67 & 0.66 & -0.46 & 0.34 & - & -0.01 & -0.18 & -0.20 & -0.11 & -0.16 & -0.19 \\
\hline Bf & -0.68 & -0.70 & -0.62 & 0.49 & -0.55 & 0.30 & -0.39 & -0.07 & - & -0.14 & -0.01 & -0.02 & 0.03 & -0.02 \\
\hline N Lat & 0.01 & 0.06 & 0.03 & 0.03 & 0.00 & 0.04 & 0.03 & -0.14 & -0.14 & & & & & \\
\hline N Lc & -0.02 & -0.02 & -0.01 & 0.02 & -0.05 & 0.06 & 0.19 & -0.06 & -0.02 & & & & & \\
\hline E Lo & 0.03 & 0.02 & 0.01 & -0.04 & 0.02 & -0.04 & 0.13 & 0.10 & 0.04 & & & & & \\
\hline Alt & -0.03 & -0.04 & -0.02 & 0.01 & -0.05 & 0.06 & 0.19 & -0.02 & 0.02 & & & & & \\
\hline AI & -0.02 & -0.02 & -0.01 & 0.03 & -0.05 & 0.07 & 0.18 & -0.10 & -0.05 & & & & & \\
\hline
\end{tabular}

$\mathrm{Dbh}=$ diameter at breast height, $\mathrm{Th}=$ trees' $^{\prime}$ height, $\mathrm{Tv}=$ trees' $^{\prime}$ volume, $\mathrm{Ts}=$ trees' slenderness, $\mathrm{Cd}=\mathrm{crown}$ diameter, $\mathrm{Cs}=$ crown slenderness, $\mathrm{Nbw}=$ number of branches per whorl, Dbd = dominant branches diameter, $\mathrm{Bf}=$ branches' finesse. $\mathrm{N}$ Lat $=$ Nordic latitude, $\mathrm{N}$ Lc $=$ Nordic latitude corrected by altitude, $\mathrm{E}$ Lo $=$ East longitude, Alt $=$ altitude . $\mathrm{AI}=$ aridity index. 435 pendula trees387 pyramidalis trees in the Soveja trial. 960 trees for each crown form in the Măneciu trial. Significant correlations are in bold. 
In the Soveja trial, negative and significant correlations resulted between conventional wood density and the quantitative traits ( -0.36 with $\mathrm{Th}$ and $\mathrm{Dbd})$, while with stability traits (Ts, Cs, Bf) wood density was in direct correlation (statistically insignificant). In the Măneciu test, the correlations of Cwd and phenotypic traits registered the same trend but only with the Nbw was the correlation significant $(\mathrm{r}=-0.33)$.

The influences of the geographic and climatic gradients of provenances' origin to the analysed phenotypic traits differed between trials and also between crown spruce forms in each trial, but the size of the correlation was very low. In the Măneciu trial, the growth traits of pendula tree were positively and significantly influenced by the latitude of the provenances' origin, while for normal crown trees significant negative influences operated, especially the altitude and longitude of provenances' origin. In the limitative environmental conditions of the Soveja trial, pendula trees were influenced especially by the altitude and the aridity index of the provenances' origin, while for normal crown trees the influence of gradients was very low and with significance only for branches' traits. In the Soveja test, $\mathrm{Bf}$ (for both crown spruce forms) were negative and significantly influenced only by the latitude of the provenance origin stand $(r=-0.14)$, while in the Măneciu trial, the influence of the same geographical parameter was again negative but insignificant for pendula trees, while for normal crown trees the correlation was positive and significant (Table 4).

In the limitative environmental conditions of the Soveja trial, conventional wood density was in direct but insignificant correlation with the gradients of the provenances' origin place, and the highly intensive correlation $(r=0.23)$ registered with latitude. In the optimal conditions of the Măneciu trial, correlations between $\mathrm{Cwd}$ and the gradients of the provenances' origin place were negative, with significant level registered for latitude $(r=-0.36)$ and longitude $(r=-0.33)$. The populations from the north of Romania registered superior results for growth traits in optimal environmental conditions, with negative effects on the wood density.

\section{Discussion}

Significant differences between the eight Norway spruce provenances and within them, between the two crown forms, suggest a high adaptation potential to the expected climate changes of the future [48]. At the same time, the different reaction capacity of species in different environmental conditions, reported also in other studies [49-51], recommended extreme caution in the movement of forest reproductive materials.

The average tree height (Th) of the 1920 trees in the Măneciu trial was $16.2 \mathrm{~m}$, a value that exceeds the Romanian production tables (up to the upper limit of the first production class for Norway spruce, at age 25 years), which underlines the superiority of these provenances. In the limitative conditions of the Soveja trial, where the land was of inferior quality, the average $\mathrm{Th}, 11.5 \mathrm{~m}$, falls in the lower limit of the second production trees class, which corresponds also to superior stand productivity. The average Th of all 2742 trees of the two trials was $14.8 \mathrm{~m}$, a value similar to that registered in France [52] and $17 \%$ bigger than the results from Finland and Norway $[53,54]$, in trials with medium environmental conditions and similar age.

Trees' slenderness (Ts) average value registered by narrow crowned trees in the Soveja trial was very close to the optimal value (80) for Norway spruce stands' stability in Romanian Carpathians recommended by Popa [47]. Even if the purpose of ex situ conservation of the species was mainly for the productivity and quality of wood, in the current context of climate change, adaptability seems to be the primary consideration. Therefore, the provenances tested in the Soveja trial which have been shown to have high adaptability, can be considered as a solution for the assisted migration of the species, both in terms of ex situ conservation of the species and their ability to suit extreme climatic conditions (wind and snow breakage). Unfortunately, in the Măneciu trial, the Ts average value was very close to the threshold value (100) for the stability of spruce stands. The average Ts in trials with medium environmental conditions and close trees' age were 89 in Norway [53] and 86 in France [52]. 
An interesting result was obtained for crown diameter in the trial established in the optimal ecological conditions for Norway spruce (Măneciu trial). So, in Duncan's test, all pendula provenances were included in the first homogeneous group, being susceptible to selection in the next generation of the breeding program. In addition, in cluster analysis, all pendula were included in Cluster 2 and more than that, the provenances from the Apuseni mountains were all included in the second sub-cluster (Figure 4). At the same time, in the limitative conditions of the Soveja test, no grouping resulted from the cluster diagram and also for Duncan's test. We may conclude that, if the competition for light is stronger, the pendula react better than the normal crown form of spruce. This statement is in accordance with Finnish research, which recommended the reduction of planting schemes and no thinning intervention in narrow crowned Norway spruce stands $[3,34,35]$. In the Soveja trial, as compensation for higher values of Cd, crown slenderness (Cs) was lower by $39 \%$ than in the Măneciu test, which ensures the stand's stability.

Research carried out in the north of Europe (Finland, Sweden and Norway) reported the same result regarding the number of branches per whorl, 6-7 [55,56]. In terms of stability and also for wood quality, it is important to select trees with thin branches but, at the same time, the branches' diameter must have the smallest proportion relative to the trunk diameter. The average value for branches' finesse registered in the Măneciu trial (12.8\%) was similar to the result registered in Finland and Sweden, at the same age [56]. The fact that, in both trials, Dbd and Bf are smaller for narrow crowned trees than for normal crown ones (significant differences for three of the four values, Table 1) suggests a superiority of pendula both for wood quality and in terms of stability against heavy snow.

The average value registered for wood density by the narrow crowned trees of both trials $\left(0.371 \mathrm{~g} / \mathrm{cm}^{3}\right)$ was only $4 \%$ lower than the result reported in Finland for the same crown type, while for normal crown the average Cwd results were almost equal $\left(0.365 \mathrm{~g} / \mathrm{cm}^{3}\right.$ in Romania and $0.366 \mathrm{~g} / \mathrm{cm}^{3}$ in Finland). The Finnish results were obtained at the same trees' age, on a favourable site condition for Norway spruce and on a planting scheme a little denser than ours, $2 \mathrm{~m} \times 1.5 \mathrm{~m}$ [34]. In Finland, in a thinning experiment $(1 \mathrm{~m} \times 1 \mathrm{~m})$, wood density was lower for narrow crowned than for normal crown spruce trees [33] while the growth traits were higher, suggesting superior adaptability of narrow crowned form to the denser planting scheme. The same as in the present work, previous research has reported a much smaller variation for wood density than growth traits [57,58].

As in the present paper, numerous previous studies resulted in positive and highly intensive correlations between growth traits, but, at the same time, a direct and significant correlation between growth and qualitative/stability traits $[34,59,60]$, which cancels the possibility of simultaneous selection after growth and wood quality traits. Different intensity correlations of branches' finesse and growth traits were observed between trials (much more intensive in the Soveja test, in limitative environmental conditions), suggesting that, when the competition for light is lower the Bf proportion of trunk strongly decreases. Low-intensity correlations between the analysed traits and the gradients of provenances' origin have been registered before in Romania [60], in contradiction with other studies [48]. It is possible that the climatic conditions in the area of provenances' origin do not follow any geographic trend.

Negative correlations between wood density and growth traits are in accordance with previous research $[34,57,61-63]$ suggesting that a reduced competition between trees may increase the stand's stability.

\section{Conclusions}

In both trials, no significant differences were observed between spruce crown forms for the growth traits. In both trials, but especially in the limitative environmental conditions of the Soveja trial, the narrow-crowned form of Norway spruce (Picea abies $\mathrm{f}$. pendula) presented more favourable average results than the normal crown spruce form (pyramidalis) for the most important stand stability traits: trees' slenderness, wood density, branches' diameter and branches' finesse.

For the ensemble of the two comparative trials, the results were highly significantly $(p<0.001)$ influenced by the testing site (except for Cwd) and significantly $(p<0.05)$ influenced by the provenance 
and sometimes by the interaction between testing site, provenance and form, while the crown form was influenced significantly only in the crown and branches traits. Both the provenances and forms within them react differently to the changing of the testing site, which may lead to recommendation of the adoption, with maximum caution, of decisions regarding the transfer of forest reproductive materials.

The correlations between the analysed traits converge towards the adoption of a two-step breeding strategy, starting by selection of narrow crowned trees after stability traits.

By transforming the trials in seed sources (tested forest genetic resources) at the end of the breeding programme, it will ensure the ex situ conservation of the best provenances that can be used for the production of reproductive materials available for ecological sectors similar to the test site, suitable under future climate scenarios.

Supplementary Materials: The following are available online at http://www.mdpi.com/1999-4907/10/5/395/s1, Figure S1: Example of field design: Replication 2 in Măneciu trial. Table S1: ANOVA for the phenotypic traits in Măneciu and Soveja trials.

Author Contributions: E.N.A. was responsible for data collection, statistical analyses and also in the stage of writing the article. M.B. participated in the collection of field data, data analysis and writing of the article.

Funding: This paper was financed by the Romanian Ministry of Research and Innovation, in the frame of National Research-Development Nucleus Programme contracted with "Marin Drăcea" National Institute for Research and Development in Forestry (Projects PN18040203 and PN19070302).

Acknowledgments: The authors express their gratitude to anonymous reviewers for their important contribution in the manuscript improvement. We would like to thank also to Cambridge Proofreading LLC (England) for polishing the English text and to our devoted colleagues: Dan Pepelea, Ivan Robert and Ştefan Tănasie, for their help in the field measurements.

Conflicts of Interest: The authors declare no conflict of interest.

\section{References and Notes}

1. Boisvenue, C.; Running, S.W. Impacts of climate change on natural forest productivity-evidence since the middle of the 20th century. Glob. Chang. Biol. 2006, 12, 862-882. [CrossRef]

2. Pretzsch, H.; Block, J.; Dieler, J.; Dong, P.H.; Kohnle, U.; Nagel, J.; Spellmann, H.; Zingg, A. Comparison between the productivity of pure and mixed stands of Norway spruce and European beech along an ecological gradient. Ann. For. Sci. 2010, 67, 712. [CrossRef]

3. Rodriguez, Y.P.; Morales, L.; Willför, S.; Pulkkinen, P.; Peltola, H.; Pappinen, A. Wood decay caused by Heterobasidion parviporum in juvenile wood specimens from normal- and narrow-crowned Norway spruce. Scand. J. For. Res. 2013, 28, 331-339. [CrossRef]

4. Kauppi, P.E.; Posch, M.; Pirinen, P. Large impacts of climatic warming on growth of boreal forests since 1960. PLoS ONE 2014, 9, e111340. [CrossRef]

5. Keenan, R.J. Climate change impacts and adaptation in forest management: a review. Ann. For. Sci. 2015, 72, 145-167. [CrossRef]

6. Pretzsch, H.; Dieler, J. The dependency of the size-growth relationship of Norway spruce (Picea abies (L.) Karst.) and European beech (Fagus sylvatica (L.)) in forest stands on long-term site conditions, drought events, and ozone stress. Trees 2011, 25, 355-369. [CrossRef]

7. Pretzsch, H.; Biber, P.; Schütze, G.; Kemmerer, J.; Uhl, E. Wood density reduced while wood volume growth accelerated in Central European forests since 1870. For. Ecol. Manag. 2018, 429, 589-616. [CrossRef]

8. Steffenrem, A.; Solheim, H.; Skrøppa, T. Genetic parameters for wood quality traits and resistance to the pathogens Heterobasidion parviporum and Endoconidiophora polonica in a Norway spruce breeding population. Eur. J. For. Res. 2016, 135, 815-825. [CrossRef]

9. Bouriaud, O.; Leban, J.-M.; Bert, D.; Deleuze, C. Intra-annual variations in climate influence growth and wood density of Norway spruce. Tree Physiol. 2005, 25, 651-660. [CrossRef]

10. Franceschini, T.; Bontemps, J.-D.; Gelhaye, P.; Rittie, D.; Herve, J.-C.; Gegout, J.-C.; Leban, J.-M. Decreasing trend and fluctuations in the mean ring density of Norway spruce through the twentieth century. Ann. For. Sci. 2010, 67, 816. [CrossRef] 
11. Franceschini, T.; Bontemps, J.-D.; Leban, J.-M. Transient historical decrease in earlywood and latewood density and unstable sensitivity to summer temperature for Norway spruce in northeastern France. Can. J. For. Res. 2012, 42, 219-226. [CrossRef]

12. Reyer, C.; Lasch-Born, P.; Suckow, F.; Gutsch, M.; Murawski, A.; Pilz, T. Projections of regional changes in forest net primary productivity for different tree species in Europe driven by climate change and carbon dioxide. Ann. For. Sci. 2014, 71, 211-225. [CrossRef]

13. Anderegg, W.R.; Klein, T.; Bartlett, M.; Sack, L.; Pellegrini, A.F.; Choat, B.; Jansen, S. Meta-analysis reveals that hydraulic traits explain cross-species patterns of drought-induced tree mortality across the globe. Proc. Natl. Acad. Sci. USA 2016, 113, 5024-5029. [CrossRef] [PubMed]

14. Jupa, R.; Plavcová, L.; Gloser, V.; Jansen, S. Linking xylem water storage with anatomical parameters in five temperate tree species. Tree Physiol. 2016, 36, 756-769. [CrossRef] [PubMed]

15. Vlad, R.; Zhiyanski, M.; Dincă, L.; Sidor, C.G.; Constandache, C.; Pei, G.; Ispravnic, A.; Blaga, T. Assessment of the density of wood with stem decay of Norway spruce trees using drill resistance. Proc. Bulg. Acad. Sci. 2018, 71, 1502-1510. [CrossRef]

16. Hacke, U.G.; Jansen, S. Embolism resistance of three boreal conifer species varies with pit structure. New Phytol. 2009, 182, 675-686. [CrossRef]

17. Rosner, S. Hydraulic and biomechanical optimization in Norway spruce trunkwood: A review. IAWA J. 2013, 34, 365-390. [CrossRef]

18. Rosner, S.; Světlík, J.; Andreassen, K.; Børja, I.; Dalsgaard, L.; Evans, R.; Karlsson, B.; Tollefsrud, M.M.; Solberg, S. Wood density as a screening trait for drought sensitivity in Norway spruce. Can. J. For. Res. 2014, 44, 154-161. [CrossRef]

19. Kärkkäinen, M.; Marcus, M. Shrinkage properties of Norway spruce wood. Silva. Fenn. 1985, 19, 67-72. [CrossRef]

20. Mayr, S.; Cochard, H. A new method for vulnerability analysis of small xylem areas reveals that compression wood of Norway spruce has lower hydraulic safety than opposite wood. Plant Cell Environ. 2003, 26, 1365-1371. [CrossRef]

21. Hietz, P.; Rosner, S.; Sorz, J.; Mayr, S. Comparison of methods to quantify loss of hydraulic conductivity in Norway spruce. Ann. For. Sci. 2008, 65, 502-508. [CrossRef]

22. Rosner, S.; Karlsson, B.; Konnerth, J.; Hansmann, C. Shrinkage processes in standard-size Norway spruce wood specimens with different vulnerability to cavitation. Tree Physiol. 2009, 29, 1419-1431. [CrossRef] [PubMed]

23. Bouche, P.S.; Jansen, S.; Cruz Sabalera, J.; Cochard, H.; Burlett, R.; Delzon, S. Low intra-tree variability in resistance to embolism in four Pinaceae species. Ann. For. Sci. 2016, 73, 681-689. [CrossRef]

24. Rosner, S. Wood density as a proxy for vulnerability to cavitation: Size matters. J. Plant Hydraul. 2017, 4, e-001. [CrossRef]

25. Şofletea, N.; Curtu, A.L. Dendrologie (Dendrology); Transylvania University Publishing House: Braşov, Romania, 2007; p. 540. (In Romanian)

26. Pârnuţă, G.; Stuparu, E.; Budeanu, M.; Scărlătescu, V.; Marica, F.-M.; Lalu, I.; Filat, M.; Tudoroiu, M.; Lorenţ, A.; Daia, M.; et al. Catalogul naţional al resurselor genetice forestiere (National Catalogue of Forest Genetic Resources); Silvică Publishing House: Bucharest, Romania, 2011; p. 525. (In Romanian)

27. Pârnuţă, G.; Budeanu, M.; Stuparu, E.; Scărlătescu, V.; Cheşnoiu, E.-N.; Tudoroiu, M.; Filat, M.; Nica, M.-S.; Teodosiu, M.; Lorenţ, A.; et al. Catalogul naţional al materialelor de bază pentru producerea materialelor forestiere de reproducere (National Catalogue of Basic Materials for Production of Forest Reproductive Materials); Silvică Publishing House: Bucharest, Romania, 2012; p. 304. (In Romanian)

28. Karki, L. Genetically narrow-crowned trees combine high timber quality and high stem wood production at low cost. In Crop Physiology of Forest Trees; Landsberg, J.J., Ed.; Tigerstedt Editure: Helsinki, Finland, 1985; pp. 245-256.

29. Pârnuţă, G. Variabilitatea genetică şi ameliorarea arborilor de molid cu coroană îngustă în România (Genetic Variability and Breeding of Narrow-Crowned Norway Spruce Trees in Romania); Silvică Publishing House: Bucharest, Romania, 2008; p. 181, (In Romanian with English abstract).

30. Pulkkinen, P.; Pöykkö, T. Inherited narrow crown form, harvest index and stem biomass production in Norway spruce, Picea abies. Tree Physiol. 1990, 6, 381-391. [CrossRef] [PubMed] 
31. Pöykkö, T. A short-term breeding programme applying the ideotype concept. In Proceedings of the Nordic group for tree breeding. Joint Session of the European Forestry Commission and the Timber Committee, Edinburgh, UK, October 1993; pp. 110-117.

32. Geburek, T.; Robitschek, K.; Milasowszky, N. A tree of many faces: Why are there different crown types in Norway spruce (Picea abies (L.) Karst.)? Flora 2008, 203, 126-133. [CrossRef]

33. Zubizarreta Gerendiain, A.; Peltola, H.; Pulkkinen, P.; Ikonen, V.-P.; Jaatinen, R. Differences in growth and wood properties between narrow and normal crowned types of Norway spruce grown at narrow spacing in Southern Finland. Silva. Fenn. 2008, 42, 423-437. [CrossRef]

34. Zubizarreta Gerendiain, A.; Peltola, H.; Pulkkinen, P. Growth and wood property traits in narrow crowned Norway spruce (Picea abies f. pendula) clones grown in southern Finland. Silva. Fenn. 2009, 43, 369-382. [CrossRef]

35. Kuuluvainen, T. Crown architecture and stemwood production in Norway spruce (Picea abies (L.) Karst.). Tree Physiol. 1988, 4, 337-346. [CrossRef]

36. Lehner, A.; Campbell, M.A.; Wheeler, N.C.; Pöykkö, T.; Glössl, J.; Kreike, J.; Neale, D.B. Identification of a RAPD marker linked to the pendula gene in Norway spruce (Picea abies (L.) Karst. f. pendula). Theor. Appl. Genet. 1995, 91, 1092-1094. [CrossRef]

37. Caré, O.; Müller, M.; Vornam, B.; Höltken, A.M.; Kahlert, K.; Krutovsky, K.V.; Gailing, O.; Leinemann, L. High morphological differentiation in crown architecture contrasts with low population genetic structure of German Norway spruce stands. Forests 2018, 9, 752. [CrossRef]

38. Dănescu, F.; Costăcheschu, C.; Mihăilă, E. Sistematica staţiunilor forestiere (Systematic of Forest Sites); Silvică Publishing House: Bucharest, Romania, 2010; p. 253. (In Romanian)

39. Anonymous. Management planning of production unit II Soveja, forest district Soveja, 2012.

40. Anonymous. Management planning of production unit IV Suzana, forest district Măneciu, 2008.

41. Giurgiu, V.; Decei, I.; Drăghiciu, D. Metode şi tabele dendrometrice (Methods and Dendrometrical Tables); Ceres: Bucharest, Romania, 2004; p. 575. (In Romanian)

42. Dumitriu-Tătăranu, I.; Ghelmeziu, N.; Florescu, I.; Milea, I.; Moş, V.; Tocan, M. Estimarea calităţii lemnului prin metoda carotelor de sondaj (Estimation of Wood Quality by Sampling Cores Method); Tehnică Publishing House: Bucharest, Romania, 1983; p. 348. (In Romanian)

43. Şofletea, N.; Budeanu, M.; Pârnuţă, G. Provenance variation in radial increment and wood characteristics revealed by 30 years old Norway spruce comparative trials. Silvae Genet. 2012, 61, 170-178. [CrossRef]

44. STATISTICA, version 10.0; StatSoft Inc.: Tulsa, OK, USA, 2010.

45. Nanson, A. Génétique et amélioration des arbres forestières (Genetic and Forest Trees Breeding); Les presses agronomique de Gembloux: Gembloux, Belgium, 2004; p. 712. (In French)

46. Viersma, J.H. Enquête kwantitatieve aspecten van het exotenvraagstuk (Survey quantitative aspects of the exotics species). Ned. Bosb. Tijtschr. 1962, 34, 175-184. (In Dutch)

47. Popa, I. Wind throw-risk factor in mountainous forest ecosystems. Ann. For. Res. 2005, 48, 3-28.

48. Eriksson, G. Picea abies Recent Genetic Research; Swedish University of Agricultural Sciences: Uppsala, Sweden, 2010; p. 192.

49. Moberg, L. Predicting knot properties of Picea abies and Pinus sylvestris from generic tree descriptors. Scand. J. For. Res. 2006, 21, 49-62. [CrossRef]

50. Kantola, A.; Mäkinen, H.; Mäkelä, A. Stem form and branchiness of Norway spruce as a sawn timber-Predicted by a process based model. For. Ecol. Manag. 2007, 241, 209-222. [CrossRef]

51. Barszcz, A.; Sandalak, A.; Sandalak, J. Knottiness of spruce stems from the Dolomites as the basis for distinguishing quality zones in round wood. Folia For. Pol. Ser. A 2010, 52, 89-97.

52. Loubère, M.; Saint-André, L.; Hervé, J.-C.; Vestøl, G.I. Relationships between stem size and branch basal diameter variability in Norway spruce (Picea abies (L.) Karsten) from two regions of France. Ann. For. Sci. 2004, 61, 525-535. [CrossRef]

53. Steffenrem, A.; Saranpää, P.; Lundqvist, S.-O.; Skrøppa, T. Variation in wood properties among five full-sib families of Norway spruce (Picea abies). Ann. For. Sci. 2007, 64, 799-806. [CrossRef]

54. Kilpelainen, A.; Routa, J.; Peltola, H.; Zubizarreta Gerendiain, A.; Pulkkinen, P.; Kellomaki, S. Effects of genetic entry and competition on above ground biomass production of Norway spruce grown in southern Finland. For. Ecol. Manag. 2010, 259, 2327-2332. [CrossRef] 
55. Skrøppa, T. Diallel crosses in Picea abies. II. Performance and inbreeding depression of selfed families. For. Genet. 1996, 3, 69-79.

56. Mäkinen, H.; Ojansuu, R.; Sairanen, P.; Yli-Kojola, H. Predicting branch characteristics of Norway spruce (Picea abies (L.) Karst.) from simple stand and tree measurements. Forestry 2003, 76, 525-546. [CrossRef]

57. Hannrup, B.; Calahan, C.; Chantre, G.; Grabner, M.; Kalrlsson, B.; Le Bayon, I.; Lloyd Jones, G.; Müller, U.; Pereira, H.; Rodriques, J.C.; et al. Genetic parameters of growth and wood quality traits in Picea abies. Scand. J. For. Res. 2004, 19, 14-29. [CrossRef]

58. Zubizarreta Gerendiain, A.; Peltola, H.; Pulkkinen, P.; Jaatinen, R.; Pappinen, A.; Kellomäki, S. Differences in growth and wood property traits in cloned Norway spruce (Picea abies). Can. J. For. Res. 2007, 37, 2600-2611. [CrossRef]

59. Hein, S.; Mäkinen, H.; Yue, C.; Kohnle, U. Modelling branch characteristics of Norway spruce from wide spacings in Germany. For. Ecol. Manag. 2007, 242, 155-164. [CrossRef]

60. Budeanu, M.; Şofletea, N.; Petriţan, I.C. Among-population variation in quality traits in two Romanian provenance trials with Picea abies L. Balt. For. 2014, 20, 37-47.

61. Gräns, D.; Hannrup, B.; Isik, F.; Lundqvist, S.O.; McKeand, S. Genetic variation and relationships to growth traits for microfibril angle, wood density and modulus of elasticity in a Picea abies clonal trial in southern Sweden. Scand. J. For. Res. 2009, 24, 494-503. [CrossRef]

62. Steffenrem, A.; Kvaalen, H.; Høibø, O.A.; Edvardsen, Ø.M.; Skrøppa, T. Genetic variation of wood quality traits and relationships with growth in Picea abies. Scand. J. For. Res. 2009, 24, 15-27. [CrossRef]

63. Chen, Z.-Q.; Karlsson, B.; Mörling, T.; Olsson, L.; Mellerowicz, E.; Wu, H.; Lundqvist, S.-O.; Gil, M.R.G. Genetic analysis of fiber dimensions and their correlation with stem diameter and solid-wood properties in Norway spruce. Tree Genet. Gen. 2016, 12, 123. [CrossRef]

(C) 2019 by the authors. Licensee MDPI, Basel, Switzerland. This article is an open access article distributed under the terms and conditions of the Creative Commons Attribution (CC BY) license (http://creativecommons.org/licenses/by/4.0/). 